\title{
Helicobacter pylori and upper gastrointestinal diseases: A review
}

\author{
Bruna Maria Roesler ${ }^{*}$, Elizabeth Maria Afonso Rabelo-Gonçalves, \\ José Murilo Robilotta Zeitune
}

Department of Clinical Medicine, Center of Diagnosis of Digestive Diseases, Faculty of Medical Sciences, State University of Campinas, Campinas, Brazil; "Corresponding Author: roeslerbruna@gmail.com

Received 25 November 2013; revised 2 January 2014; accepted 11 January 2014

Copyright (c) 2014 Bruna Maria Roesler et al. This is an open access article distributed under the Creative Commons Attribution License, which permits unrestricted use, distribution, and reproduction in any medium, provided the original work is properly cited. In accordance of the Creative Commons Attribution License all Copyrights @ 2014 are reserved for SCIRP and the owner of the intellectual property Bruna Maria Roesler et al. All Copyright (C) 2014 are guarded by law and by SCIRP as a guardian.

\section{ABSTRACT}

Since its first isolation by Marshall and Warren, Helicobacter pylori $(H$. pylori) has been recognized to have a causal role in the upper gastrointestinal diseases development, especially in chronic gastritis, peptic ulcer disease, mucosa-associated lymphoid tissue (MALT lymphoma) and gastric adenocarcinoma. H. pylori is a spiral-shaped gram-negative flagellate bacterium that has a high genetic diversity, which is an important factor in its adaptation to the host stomach and also for the clinical outcome of the infection, an aspect that remains unclear. However, it is thought to involve a interplay among the virulence of the infecting strain, host genetics and environmental factors. This review chapter brings the principal characteristics of the diseases associated with $H$. pylori infection and summarizes some important characteristics concerning the virulence of bacterium strain, host genetics and external environment.

\section{KEYWORDS}

\section{Helicobacter pylori; Gastritis; Peptic Ulcer Disease; MALT Lymphoma; Gastric Cancer}

\section{INTRODUCTION}

Helicobacter pylori (H. pylori) remains one of the most common worldwide human infections and, although colonization with $H$. pylori is not a disease in itself, it is a condition that affects the relative risk of developing various clinical disorders of the upper gastrointestinal tract, and possibly the hepatobiliary tract [1]. Consequently, since the successful isolation of $H$. pylori by Marshall and Warren [2], H. pylori infection has been recognized to have a causal role in gastritis, peptic ulcer disease, mucosa-associated lymphoid tissue (MALT lymphoma) and gastric adenocarcinoma [3]. In 1994, the bacterium was classified as a group I carcinogen by the International Agency for Research on Cancer and is regarded as a primary factor for gastric cancer development [4]. For their revolutionary discovery, Marshall and Warren received the Nobel Prize in Physiology or Medicine in 2005.

Gastric colonization with $H$. pylori affects at least half the world's population, and, while the infection is on a fast decline in most of the western countries, mainly due to the success of therapeutic regimens and improved personal and community hygiene that prevents re-infection, the situation is exactly opposite in many of the developing countries due to failure of treatment and emergence of drug resistance [5,6].

The routes of transmission of $H$. pylori still remain unclear. Person-to-person transmission and intrafamilial spread seem to be the main route, based on the intrafamilial clustering observed in some studies $[7,8]$. Children are often infected by a strain which a genetic fingerprint identical to that of their parents, and they maintain this genotype even after moving to a different environment [9]. Besides, the waterborne infection remains possible $[10,11]$.

H. pylori populations are highly diverse and constantly change their genome, which can be an important factor in its adaptation to the host stomach and also for the clinical outcome of the infection. The changes in its genome occur mainly due to point mutations, substitutions, insertions, and/or deletions of their genome. Moreover, mixed infections are frequent and lead to exchange of DNA fragments between different $H$. pylori strains in a single host [12,13]. 
Although $H$. pylori is primarily responsible for the upper gastrointestinal diseases, only less than $10 \%$ of people colonized with this bacterium portray disease symptoms. It suggests that host and bacterial factors also contribute to differences in $H$. pylori pathogenicity $[3,14]$. Besides, the environment can be important in this relationship, especially with regards to the dietary habit, smoking and alcohol consumption. For instance, the risk of developing gastric cancer is also related to genetic characteristics of the host and environmental factors, which, associated with specific bacterial strain characteristics, influence the severity of the chronic inflammatory response $[15,16]$.

Besides, in the last decades, in studies that are expressly aimed at demonstrating how $H$. pylori may cause gastric mucosal damage and, at the same time, elude the immunological response evoked by the host [17], H. pylori infection has been associated with extradigestive diseases [18], such as iron-deficiency anemia [19], idiopathic thrombocytopenic purpura [20,21], cardiovascular diseases [22,23], and hepatobiliary diseases [24,25], among others.

Consequently, the aim of this review manuscript is to summarize the principal characteristics of the upper gastrointestinal diseases associated with $H$. pylori infection, including some important studies concerning this subject.

\section{UPPER GASTROINTESTINAL DISEASES}

\subsection{Helicobacter pylori-Induced Gastritis}

Gastritis is an inflammatory condition of the gastric mucosa that can affect different regions of the stomach and show different degrees of mucosal injury. Many kinds of agents may lead the stomach into an inflamed state. For instance, it could be due to non-steroidal antiinflammatory drugs (NSAIDs) such as aspirin, naproxen and ibuprofen, usually used in some specific illness such as rheumatoid arthritis; due to abrasive compounds or unbalanced diets where the stomach is damaged by its own gastric acid; due to a long-term physical and/or mental stress that result in the production of excessive amounts of gastric acid; and, finally, due to Helicobacter pylori (H. pylori) infection. Besides, infections such as cytomegalovirus, chronic idiopathic inflammatory and autoimmune disorders such as Crohn's disease and pernicious anemia and chemical damage due to alcohol abuse are other causes of gastritis.

In fact, the history of chronic gastritis can be divided into two phases: before and after the isolation of $\mathrm{H}$. pylori [2]. Until then, lack of knowledge of its biological nature has resulted in non interest of most clinicians and gastroenterologists, who considered the chronic gastritis not as an etiopathogenic factor, but a result of an event or a consequence of gastric diseases. Many researchers considered that gastric mucosa was always swollen (infiltrated with mononuclear inflammatory cells), similar to the lining of the distal intestine and, consequently, this condition was not used having a great importance in the clinical practice and diagnostic. Consequently, nowadays, there is no doubt that $H$. pylori infection is responsible for the majority of cases of gastritis $[1,26]$.

Colonization with $H$. pylori virtually leads to infiltration of the gastric mucosa in both antrum and corpus with neutrophilic and mononuclear cells. Gastritis can be classified as an acute or chronic gastritis and it can involve all parts of the stomach or just the fundus, corpus or antrum. The chronic active gastritis is the primary condition related to $H$. pylori colonization, and other $H$. pylori-associated disorders, in particular, resulting from this chronic inflammatory process [1], as atrophic gastritis, causing an elevated risk of gastric cancer [27].

\subsubsection{Acute Gastritis}

The acute phase of colonization with $H$. pylori may be associated with transient non-specific dyspeptic symptoms, such as fullness, nausea, and vomiting, and with some considerable inflammation of both the proximal and distal stomach mucosa, or pangastritis. This phase is often associated with hypochlorhydria, which can last for months [1]. It is unclear whether this initial colonization can be followed by spontaneous clearance and resolution of gastritis and, if so, how often it occurs. Follow-up studies of young children suggested that infection may spontaneously disappear in some patients in this age group [28-30]. This condition has not been observed in adults other than under specific circumstances, such as the development of atrophic gastritis. Consequently, some individuals are prone to $H$. pylori colonization while others may be able to prevent colonization or clear an established infection [1].

\subsubsection{Chronic Gastritis}

When colonization does become persistent - chronic gastritis, a close correlation exists between the level of acid secretion and distribution of gastritis. This correlation results from the counteractive effects of acid on bacterial growth versus those of bacterial growth and associated mucosal inflammation on acid secretion and regulation. This interaction is crucial in the determination of outcomes of $H$. pylori infection.

Chronic gastritis due to $H$. pylori infection may be separated into distinct, clinically relevant phenotypes [31]. Nonatrophic pangastritis occurs in the majority of $H$. pylori-infected individuals with no predisposition to peptic ulcer disease or gastric atrophy. Prominent mucosal inflammation in chronic active gastritis often is evident in the antrum (antral-predominant gastritis), predisposing 
to hyperacidity and duodenal ulcer disease. In contrast, multifocal atrophic pangastritis and atrophic corpuspredominant gastritis result from long-standing infections and are characterized by glandular atrophy, intestinal metaplasia, and sparse inflammatory cells [32]. Both forms of atrophic gastritits and the presence of intestinal metaplasia are associated with an increased risk of gastric adenocarcinomas development [33].

Virulence factors of bacterium strains are important factors here because depending on them, in conjunction with host characteristics and environment, some individuals may develop severe diseases as peptic ulcer and gastric cancer.

\subsection{Helicobacter pylori-Associated Peptic Ulcer Disease}

H. pylori infection is one of the most common chronic bacterial infections worldwide with up to a half of the world's population infected [13]. It is believed that bacterium has been colonizing the gastric mucosa of modern humans since their migration out of Africa 60,000 years ago [34]. Although the majority of subjects infected with bacterium remain asymptomatic, essentially all develop chronic inflammation [35]. However, peptic ulcer disease (PUD) and gastric carcinoma occur only in a subset of individuals chronically infected with $H$. pylori and both bacterial and host factors contribute to this differential response [36].

Interestingly, during $H$. pylori infection, a subset of the colonized subjects can develop antral-predominant gastritis, which is associated with gastric hyperchlorydria and an increased risk of duodenal ulcer (DU); another subset of the colonized subjects can develop corpus gastritis, that is associated with gastric hypochlorydria, gastric atrophy, gastric ulcer (GU) and an increased risk of non-cardia gastric cancer [37-39].

The relationship between $H$. pylori and PUD and also peptic ulcer bleeding (PUB) has been extensively studied. In fact, $H$. pylori infection is the major cause of PUD and its eradication is vital for ulcer healing in the absence of proton pump inhibitors (PPI) [40]. Furthermore, effective $H$. pylori eradication reduces the rate of ulcer recurrence and it is believed that bacterial eradication also prevents recurrence of PUB [41]. As a consequence of $H$. pylori eradication therapy, the prevalence of PUD has been declined.

In 2001, a meta-analysis of 24 studies including 2102 subjects demonstrated that ulcer healing rates in $\mathrm{H}$. pylori-eradicated patients were significantly higher compared with patients with persistent infection (98\% vs. 57.5\% for DU and $97.1 \%$ vs. $60.9 \%$ for GU) [42]. In relation to PUB, a meta-analysis conducted in 2002 confirmed that the association between $H$. pylori infection increased the risk of bleeding (OR 1.79) [43].

Considering the use of NSAID and $H$. pylori infection, both of them are considered independent risk factors for the development of PUD and ulcer bleeding. However, there is a synergistic effect for the development of bleeding when these factors are both present [44]. There are sufficient data to suggest that $H$. pylori significantly damages the gastric and duodenal mucosa through direct pathogenic mechanisms, whereas NSAIDs indirectly promote injury through disruption of mucosal defensive mechanisms $[45,46]$. Therefore, current guidelines recommend $H$. pylori screening and treatment prior to initiating long-term NSAID therapy in patients with a history of PUD [44].

In addition, the role of environmental factors other than H. pylori and NSAID, as well as social factors, in the natural history of ulcer has not been adequately explored. Diet may be the most important of these factors, the others being alcohol, tobacco, stress and shift work [47]. A review study about diet and duodenal ulcer performed in 2000 demonstrated that fibre, mainly soluble fibres from fruit and vegetables, and perhaps poly-unsaturated fatty acids, vitamin A and C, appear to be inversely associated with the occurrence of duodenal ulcer, while refined sugars seem to be directly associated with the disease [48].

In relation to $H$. pylori virulence factors in the development of PUD, the role of cagA gene and vacA gene was verified in a systematic review of 44 studies. CagA positivity was associated with an increased risk for PUD [(OR 1.69 (95\% CI 1.12 - 2.55)] and individuals infected with $\mathrm{s} 1 \mathrm{~m} 1$ strains were also associated with PUD [OR 2.04 (1.01 - 4.13)] [49]. More recently, a novel virulence factor, duodenal ulcer promoting gene A $(\operatorname{dup} A)$ has been identified and found to be associated with duodenal ulcer in some populations. A current meta-analysis investigated the relationship of dupA genotypes and $H$. pylorirelated clinical outcomes in 2358 patients from around the world with $d u p A$-positive genotypes. It was observed that $\operatorname{dup} A$ was associated with duodenal ulcer in $48 \%$ of subjects $[\mathrm{p}=0.001, \mathrm{OR}=1.4,(\mathrm{CI}=1.1-1.7)$; however, the $\operatorname{dup} A$ positivity and its association with disease differed among the various regions around the world [50]. In a Brazilian study, dupA was found both in early and advanced gastric adenocarcinoma, suggesting that, together with cagA gene, it could be an important virulence factor in the development of this disease [51].

Then, researchers continue to explore the complexities of $H$. pylori infection, trying to explain why some individuals have asymptomatic infection, whereas others experience clinical disease. The importance of treating $H$. pylori infection in patients with gastrointestinal problems has been confirmed in recent years especially in the prevention of the development of PUD and gastric cancer. 


\subsection{H. pylori-Associated Gastric MALT-Lymphoma}

Primary gastric lymphoma (PGL) is a rare tumour, accounting for $<5 \%$ of primary gastric neoplasms [52]. Most PGL is non-Hodgking type B lymphoma, derived from mucosa associated lymphoid tissue (MALT) that represents about $4 \%$ to $20 \%$ of non-Hodgkin lymphoma and more than $50 \%$ of the PGL [53-55].

The MALT lymphomas were first described in 1983 for Isaacson and Wright [56] and represent an extranodal lymphoma consisting mainly of morphologically heterogeneous small B cells [57]. Histologically, MALT lymphomas are characterized by lymphocytic infiltrate with invasion and partial destruction of the gastric glands and the crypts by aggregates of tumor cells infiltrating the lamina propria diffusely and growing around reactive follicles [58].

The lymphoid tissue is not commonly found in the stomach and its appearance is related, in general, to $H$. pylori infection [59]. In fact, $H$. pylori infection is associated with approximately $80 \%$ of gastric MALT lymphomas [60]. The first study correlating the bacteria with MALT lymphoma was carried out by Wotherspoon et al. (1991) [61] that not only observed the presence of bacteria in almost all cases of gastric MALT lymphoma that they studied, but also showed that infection resulted in accumulation of MALT in gastric mucosa. These results were further confirmed by other researchers [62-64]. Additionally, experimental studies using rats and mice infected with $H$ felis also supported these findings [6567].

In 2002, a review of 24 studies including 780 patients found that complete lymphoma regression after $H$. pylori eradication was achieved in 35\% - 100\% of patients, depending on the disease stage [68]. After that, a systematic review involving a total of 1844 patients from 38 studies demonstrated that the prevalence of $H$. pylori infection in MALT lymphoma was 79\%, with higher rate in low-grade (79\%) than in high-grade (60\%) cases [58]. In other studies, the eradication of $H$. pylori caused a complete remission in $60 \%-80 \%$ of patients with MALT lymphoma [1,69] and a 10-year sustained remission in up to $64 \%$ of patients [70]. Then, there is a consensus that $H$. pylori eradication should be performed in all cases of gastric MALT lymphoma, regardless of stage of disease and prognostic factor status, considering that it is a fast and simple strategy to avoid a bacterial trigger of the immune response [71].

The pathogenic mechanism of $H$. pylori infection in MALT lymphoma remains unclear, although the causal relationship between infection and disease has been proven. It is well established that $H$. pylori infection induces an immune response of Th1 type mediated by several proinflammatory cytokines, leading to chronic ga- stritis with formation of lymphoid follicles in the stomach [72,73]. As well as triggering immunological responses that stimulates the growth of malignant B cells, $H$. pylori infection also triggers inflammatory responses by attracting and activating neutrophils, which release reactive oxygen species (ROS). These ROS can evoke a wide range of gastric damage and might therefore have a role in the acquisition of genetic abnormalities in gastric MALT lymphoma [74]. The severity of DNA damage occurring in an infected individual will depend on a number of factors, including the bacterial virulence, the severity of the inflammatory response and the individual's ability to detoxify ROS [75].

Recently, progress has been made in understanding the molecular basis of MALT lymphoma and three specific major chromosomal translocations have been reported. The $\mathrm{t}(11 ; 18)$ (q21; q21)/(API2-MALT1) is found in $25 \%$ - 30\% of gastric MALT lymphomas and is associated with advanced and unresponsive lymphomas $[76,77]$. By contrast, MALT lymphomas that are negative for this translocation commonly show a wide range of chromosomal aberrations, including trisomy of chromossomes 3, 12 and 18 [78,79]. Another translocation is the $t(1 ; 14)$ (p22; q32) and it might confer to the tumor an increased capacity of autonomous growth by means of inactivating mutations and overexpression of the BCL10 gene and the $\mathrm{t}(14 ; 18)$ ( $\mathrm{q} 32$; q21) translocation is most often seen in folicular lymphoma [80]. It is interesting to note that these genetic abnormalities share a common pathogenic mechanism mediated by the activation of the $\mathrm{NF}-\kappa \mathrm{B}$ signaling pathway and might confer additional oncogenic activities as indicated by the aberrant pattern of BCL10 expression in some cases of MALT lymphoma [74].

Few studies have been conducted to verify the role of $H$. pylori virulence factors in the development of gastric MALT lymphoma. Interestingly, none of the virulence factors known for this bacterium, including the presence of the cag pathogenicity island (PAI) or the Vac toxin, could be associated with this pathology except for the vacAm2 allele [81-83]. Similar results were described when analyzed the prevalence and correlation between $H$. pylori virulence factors (cagA, cagE, vacA, iceA, babA, hopQ and oipA) and adhesins (subA and hopZ) by comparing a collection of 43 strains isolated from patients with low-grade MALT lymphoma to 39 strains isolated from patients with gastritis only. None of the genes tested were associated with MALT strains and authors concluded that MALT pathogenesis is not linked with more proinflammatory $H$. pylori strains. Furthermore, they demonstrated that in MALT patients infected with strains harboring the iceA1 allele, subA and hopZ status, the odds of developing a MALT lymphoma were 10 times higher. However, these strains were less prevalent rendering a low-sensitivity marker for MALT H. pylori 
strains.

Therefore, scientists have concentrated their efforts to better understanding the molecular events in the pathogenesis of gastric MALT lymphoma. Although a large body of data has implicated the role of $H$. pylori in the development of the disease, future investigations considering the polymorphisms involved in the immune response and molecular genetics of the host, in association with virulence factors of bacteria, are needed to clarify the pathomechanism by which gastric MALT lymphoma occurs.

\subsection{H. pylori and Gastric Adenocarcinoma}

Gastric cancer continues to be a major global health problem [84], and, despite the decreasing incidence and mortality rates observed worldwide over the last 50 years, it still ranks as a leading cause of cancer-related deaths in many parts of the world [85]. As symptoms are often absent or nonspecific in patients with the early stages of the disease, gastric cancer is usually diagnosed in an advanced stage, when curative options are limited. With exceptions in countries that have developed screening programs for early diagnoses, most patients reach treatment with cancers already in advanced stages [86]. Consequently, gastric cancer carries a poor prognosis, with an overall five-year survival rate of less than 20\% [87].

The vast majority of gastric cancers are adenocarcinomas, which can be prevalently divided into two types, the intestinal and the diffuse [88], which corresponds, respectively, to the well-differentiated type and the poorly-differentiated type, in the Japanese classification [89]. In contrast to the diffuse type, often associated with familial distribution and developed in the stomach following chronic inflammation, especially in the cardia [85], intestinal type adenocarcinomas are generally thought to be preceded by a sequence of precursor lesions [90]. It postulated that the intestinal type of gastric cancer was the end of progressive changes in the gastric mucosa, starting with chronic gastritis, followed by multifocal atrophic gastritis and intestinal metaplasia. The model was updated in 1988 and 1992 [91,92]. The following consecutive steps were recognized as: normal gastric mucosa, superficial gastritis (later renamed nonatrophic gastritis, multifocal atrophic gastritis without intestinal metaplasia, intestinal metaplasia of the complete (small intestine) type, intestinal metaplasia of the incomplete (colonic) type, low-grade dysplasia (lowgrade noninvasive neoplasia), high-grade dysplasia (high-grade noninvasive neoplasia) and invasive carcinoma [93](Correia e Piazuelo, 2012).

Unlike patients with advanced gastric cancer, patients diagnosed in an early stage of the disease present an excellent prognostic, in which a five-year survival rate is more than $90 \%$. This disorder is defined as the adenocar- cinoma that is confined to the mucosa or submucosa, irrespective of lymph-node invasion. Many early gastric cancers are believed to go through a life cycle consisting of ulcerations, followed by healing, then reulceration, and some tumors remain at this early stage for years even without treatment [94] Nevertheless, some early tumors rapdly became advanced and it is one of the principal questions concerning gastric carcinogenesis.

Various studies suggest the importance of $H$. pylori virulence factors as important keys in gastric mucosa inflammation and, consequently, in the development of gastric cancer. The principal of them is the cag pathogenicity island (cagPAI), a genetic locus that encodes a type IV secretion system (Censini et al., Franco et al.) $[95,96]$. Infection with cagA positive strains has been associated with higher degrees of inflammation of the gastric mucosa; consequently, the gene seems to play an important role in the development of gastric cancer, being crucial to the formation of the pre-cancerous lesions present in cases of intestinal type gastric adenocarcinoma [97-101]. Upon delivery into host cells, CagA protein leads to dephosphorylation of host cell proteins and morphological changes in the cell [102,103]. Additionally, CagA has been shown to interfere with $\beta$-catenin signaling [104,105] and apical-junctional complexes [106], events that have been linked to increased cell motility and oncogenic transformation in a variety of models $[107,108]$.

Obviously, gastric carcinogenesis involves the interaction of the etiologic agent (especially $H$. pylori), the host characteristics and the external environment [109]. As regards to $H$. pylori, many virulence genes have been reported to determine clinical outcomes; among those of potential significance, especially with regards to gastric cancer, are the cytotoxin-associated gene A (cagA), which was described before, the cytotoxin-associated gene $\mathrm{T}$ (cagT), the vacuolating cytotoxin gene (vacA), the duodenal-ulcer promoting gene (dupA) and the outer inflammatory protein gene (oipA).

Concerning to the host susceptibility, polymorphisms in a wide variety of genes that are present within a significant proportion of the normal population may modify the effect of environmental exposure. These gene-environmental interactions could explain the high variation in the incidence of gastric cancer observed around the world [110]. Among these genes, for example, there are cytokine genes (TNF- $\alpha$, IL-10, IL-8, IFN- $\gamma$ ) involved in the adaptive immune system [111,112] and pattern recognition factors (TLR-4, NOD-1, NOD-2) involved in initiating the innate immune system [113,114].

Host related factors for the development of disease can indicate genetic susceptibility (or resistance) or acquired influences, which may stimulate defenses of the host against environmental carcinogens like $H$. pylori [115]. The relationship between host genetic polymorphisms 
(for instance, in the IL-1) and bacterial virulence factors appears to have a crucial role in the development of the cancer, especially in infections with cagA positive, vacA $\mathrm{s} 1 \mathrm{~m} 1$ and oipA positive strains.

Finally, concerning to environmental factors, particularly diet and smoking play an important role in the pathogenesis of gastric cancer. Diets rich in complex carbohydrates, salt, pickled or smoked foods, dried fish, and cooking oil has been linked with an increased risk, while diet rich in fresh fruits and vegetables has been associated with a low risk of gastric cancer $[110,116]$.

Smoking also represents an important factor in gastric cancer development. A large study that included smoking men demonstrated an increased risk for the development of differentiated-type distal gastric cancer [117]. In Japan, a study offered persuasive evidence that tobacco smoking moderately increases the risk of gastric cancer among the Japanese population [118]. Another study that analyzed forty-two articles and compared current smokers and nonsmokers provided solid evidence to classify smoking as the most important behavioral risk factor for gastric cancer [119]. Finally, a recent study also concluded that smoking is an important factor associated with the risk of developing gastric cancer [120].

\section{CONCLUSION}

Since the discovery of $H$. pylori, several studies have focused on elucidating the microorganism pathogenicity mechanisms that are associated with disease outcome [121]. H. pylori is associated with chronic gastritis, pepticulcer disease, MALT-lymphoma and gastric cancer, including the precancerous cascade. The development of clinical outcomes depends on the interaction among $H$. pylori strain, and its virulence factors, host genetic characteristics and the external environment. To understand the clinical relevance of $H$. pylori genotyping in predicting infection outcomes, prospective studies in large populations and with appropriate controls are needed to elucidate its pathophysiology and genetics. Besides, studies considering the host characteristics and the environmental are also needed, in order to help to make H. pylorirelated diseases preventable, especially gastric cancer, that continues to be an important mortality factor worldwide.

\section{REFERENCES}

[1] Kusters J.G., Arnoud H.M. and Kuipers E. (2006) Pathogenesis of Helicobacter pylori infection. Clinical Microbiology Reviews, 19, 449-490.

http://dx.doi.org/10.1128/CMR.00054-05

[2] Marshall, M.J. and Warren, J.R. (1984) Unidentified curved bacilli in the stomach of patients with gastritis and peptic ulceration. Lancet, 1, 1311-1315.
http://dx.doi.org/10.1016/S0140-6736(84)91816-6

[3] Ahmed, N. and Sechi, L.A. (2005) Helicobacter pylori and gastroduodenal pathology: New threats of the old friend. Annals of Clinical Microbiology and Antimicrobials, 4, 1-10. http://dx.doi.org/10.1186/1476-0711-4-1

[4] International Agency for Research on Cancer. Schistosomes, liver flukes and Helicobacter pylori. IARC Working Group on the Evaluation of Carcinogenic Risks to Humans. (1994) IARC monographs on the evaluation of carcinogenic risks to humans. World Health Organization, International Agency for Research on Cancer, 61, 1-241.

[5] Blaser, M.J. (2005) An endangered species in the stomach. Scientific American, 292, 38-45. http://dx.doi.org/10.1038/scientificamerican0205-38

[6] Ahmed, N. (2005) 23 years of the discovery of Helicobacter pylori: Is the debate over? Annals of Clinical Microbiology and Antimicrobials, 4, 17-19. http://dx.doi.org/10.1186/1476-0711-4-17

[7] Urita, Y., Watanabe, T., Kawagoe, N., Takemoto, I., Tanaka, H., Kijima, S., et al. (2013) Role of infected grandmothers in transmission of Helicobacter pylori to children in a Japanese rural town. Journal of Paediatric Children Health, 49, 394-398.

http://dx.doi.org/10.1111/jpc.12191

[8] Bastos, J., Carreira, H., La Vecchia, C. and Lunet, N. (2013) Childcare attendance and Helicobacter pylori infection: Systematic review and meta-analysis. European Journal of Cancer Prevention, 22, 311-319.

http://dx.doi.org/10.1097/CEJ.0b013e32835b69aa

[9] Covacci, A., Telford, J.L., Del Giudice, G., Parsonnet, J. and Rappuoli, R. (1998) Helicobacter pylori virulence and genetic geography. Science, 284, 1328-1333. http://dx.doi.org/10.1126/science.284.5418.1328

[10] Lu, Y., Redlinger, T.E., Avitia, R., Galindo, A. and Goodman, K. (2002) Isolation and genotyping of Helicobacter pylori from untreated municipal wastewater. Applied and Environmental Microbiology, 68, 1436-1439.

http://dx.doi.org/10.1128/AEM.68.3.1436-1439.2002

[11] Bahrami, A.R., Rahimi, E. and Ghasemian Safaei, H. (2013) Detection of Helicobacter pylori in city water, dental unit's water and bottled mineral water in Isfahan, Iran. Scientific World Journal, 2013. http://dx.doi.org/10.1155/2013/280510

[12] Blaser, M.J. and Berg, D.E. (2001) H. pylori genetic diversity and risk of human disease. The Journal of Clinical Investigation, 107, 767-773. http://dx.doi.org/10.1172/JCI12672

[13] Suerbaum, S. and Michetti, P. (2002) Helicobacter infection. New England Journal of Medicine, 347, 1175-1186. http://dx.doi.org/10.1056/NEJMra020542

[14] Mégraud, F. (2001) Impact of Helicobacter pylori virulence on the outcome of gastroduodenal diseases: Lessons from the microbiologist. Digestive Diseases, 19, 99-103. http://dx.doi.org/10.1159/000050662

[15] Peek, R.M., Blaser, M.J., Mays, D.J., Forsyth, M.H., Cover, T.L., Song, S.Y., Krishna, U. and Pietenpol, J.A. (1999) Helicobacter pylori strain-specific genotypes and modulation of the gastric epithelial cell cycle. Cancer Re- 
search, 59, 6124-6131.

[16] de Vries, A.C., Haringsma, J. and Kuipers, E.J. (2007) The detection, surveillance and treatment of premalignant gastric lesions related to Helicobacter pylori infection. Helicobacter, 12, 1-15. http://dx.doi.org/10.1111/j.1523-5378.2007.00475.x

[17] Figura, N., Franceschi, F., Santucci, A., Bernardini, G., Gasbarrini, G. and Gasbarrini, A. (2010) Extragastric manifestations of Helicobacter pylori infection. Helicobacter, 15, 60-68.

http://dx.doi.org/10.1111/j.1523-5378.2010.00778.x

[18] Baudron, C.R., Franceschi, F., Salles, N. and Gasbarrini, A. (2013) Extragastric diseases and Helicobacter pylori. Helicobacter, 18, 44-51. http://dx.doi.org/10.1111/hel.12077

[19] Capurso, G., Lahner, E. Marcheggiano, A., Caruana, P., Carnuccio, A., Bordi, C., Delle Fave, G. and Annibale, B. (2001) Involvement of the corporal mucosa and related changes in gastric acid secretion characterize patients with iron deficiency anemy associated with Helicobacter pylori infection. Alimentary Pharmacology \& Therapeutics, 15, 1753-1761.

http://dx.doi.org/10.1046/j.1365-2036.2001.01101.x

[20] Pelicano, R., Franceschi, F., Saracco, G., Fagoonee, S., Roccarina, D. and Gasbarrini, A. (2009) Helicobacters and extragastric diseases. Helicobacter, 14, 58-68. http://dx.doi.org/10.1111/j.1523-5378.2009.00699.x

[21] Arnold, D.M., Bernotas, A., Nazi, I., Stasi, R., Kuwana, M., Liu, Y., Kelton, J.G. and Crowther, M.A. (2009) Platelet count response to $H$. pylori treatment in patients with immune thrombocytopenic purpura with and without H. pylori infection: a systematic review. Haematologica, 94, 850-856. http://dx.doi.org/10.3324/haematol.2008.005348

[22] Franceschi, F., Navarese, E.P., Mollo, R., Giupponi, B., De Marco, G., Merra, G., Gasbarrini, G. and Silveri, N.G. (2009) Helicobacter pylori and atherosclerosis. A review of the literature. Recent Progress in Medicine, 100, 91-96.

[23] Rogha, M., Nikvarz, M., Poumoghaddas, Z., et al. (2012) Is Helicobacter pylori infection a risk factor for coronary heart disease? ARYA Atherosclerose, 8, 5-8.

[24] Isaeva G.Sh., Abuzarova E.R., Valeeva IuV., Pozdeev O.K., Murav'eva E.V. (2009) Helicobacter pylori in patients with disorders of hepatobiliary system. Zhurnal Mikrobiologii Epidemiologii I Immunobioogiil, 2, 96-101.

[25] Pirouz, T., Zounubi, L., Keivani, H., Rakhshani, N. and Hormazdi, M. (2009) Detection of Helicobacter pylori in paraffin-embedded specimens from patients with chronic liver diseases, using the amplification method. Digestive Diseases and Sciences, 54, 1456-1459. http://dx.doi.org/10.1007/s10620-008-0522-5

[26] Dixon, M.F., Genta, R.M., Yardley, J.H. and Correa, P. and the Participants in the International Workshop on the Histopathology of Gastritis, Classification and Grading of Gastritis (1996) The updated Sydney system. American Journal of Surgical Pathology, 20, 1161-1181.

[27] Bornschein, J. and Malfertheiner, P. (2011) Gastric carcinogenesis. Langenbecks Archives of Surgery, 396, 729742. http://dx.doi.org/10.1007/s00423-011-0810-y
[28] Granstrom, M., Tindberg, Y. and Blennow, M. (1997) Seroepidemiology of Helicobacter pylori infection in a cohort of children monitored from 6 months to 11 years of age. Journal of Clinical Microbiology, 35, 468-470.

[29] Malaty, H.M., Graham, D.Y., Wattigney, W.A., Srinivasan, S.R., Osato, M. and Berenson, G.S. (1999) Natural history of Helicobacter pylori infection in childhood: 12-year follow-up cohort study in a biracial community. Clinical Infectious and Diseases, 28, 279-282.

http://dx.doi.org/10.1086/515105

[30] Pérez-Pérez, G.L., Sack, R.B., Reid, R., Santosham, M., Croll, J. and Blaser, M.J. (2003) Transient and persistent Helicobacter pylori colonization in Native American children. Journal of Clinical Microbiology, 41, 2401-2407. http://dx.doi.org/10.1128/JCM.41.6.2401-2407.2003

[31] Rubin, C.E. (1997) Are there three types of Helicobacter pylori gastritis? Gastroenterology, 112, 2108-2110. http://dx.doi.org/10.1053/gast.1997.v112.agast972108

[32] Versalovic, J. (2003) Helicobacter pylori. Pathology and diagnostic strategies. American Journal of Clinical Pathology, 119, 403-412. http://dx.doi.org/10.1309/5DTF5HT7NPLNA6J5

[33] Uemura, N., Okamoto, S., Yamamoto, S., Matsumura, M., Yamaguchi, S., Yamakido, M., Taniyama, K., Sasaki, N. and Schlemper, R.J. (2001) Helicobacter pylori infection and the development of gastric cancer. New England Journal of Medicine, 345, 784-789. http://dx.doi.org/10.1056/NEJMoa001999

[34] Linz, B., Balloux, F., Moodley, Y., Manica, A., Liu, H., Roumagnac, P., Falush, D., Stamer, C., Prugnolle, F., van der Merwe, S.W., Yamaoka, Y., Graham, D.Y., Perez-Trallero, E., Wadstrom, T., Suerbaum, S. and Achtman, M. (2007) An African origin for the intimate association between humans and Helicobacter pylori. Nature, 445, 915918. http://dx.doi.org/10.1038/nature05562

[35] Warren, J.R. (2000) Gastric pathology associated with Helicobacter pylori. Gastroenterology Clinics of North America, 29, 705-751. http://dx.doi.org/10.1016/S0889-8553(05)70139-4

[36] Kate, V., Ananthakrishnan, N. and Tovey, F.I. (2013) Is Helicobacter pylori infection the primary cause of duodenal ulceration or a secondary factor? A review of the evidence. Gastroenterology Research and Practice, 2013, Article ID: 425840. http://dx.doi.org/10.1155/2013/425840

[37] El-Omar, E.M., Penman, I.D., Ardill, J.E., Chittajallu, R.S., Howie, C. and McColl, K.E. (1995) Helicobacter pylori infection and abnormalities of acid secretion in patients with duodenal ulcer disease. Gastroenterology, 109, 681-691. http://dx.doi.org/10.1016/0016-5085(95)90374-7

[38] El-Omar, E.M., Oien, K., El-Nujumi, A., Gillen, D., Wirz, A., Dahill, S., Williams, C., Ardill, J.E. and McColl, K.E. (1997) Helicobacter pylori infection and chronic gastric acid hyposecretion. Gastroenterology, 113, 15-24. http://dx.doi.org/10.1016/S0016-5085(97)70075-1

[39] Konturek, P.C., Konturek, S.J. and Brzozowski, T. (2009) Helicobacter pylori infection in gastric cancerogenesis. Journal of Physiology and Pharmacology, 60, 3-21. 
[40] Siao, D. and Somsouk, M. (2013) Helicobacter pylori: Evidence-based review with a focus on immigrant populations. Journal of General Internal Medicine. http://dx.doi.org/10.1007/s11606-013-2630-y

[41] den Hollander, W.J., Sostres, C., Kuipers, E.J. and Lanas, A. (2013) Helicobacter pylori and nonmalignant diseases. Helicobacter, 18, 24-27. http://dx.doi.org/10.1111/hel.12074

[42] Leodolter, A., Kulig, M., Brasch, H., Meyer-Sabellek, W., Willich, S.N. and Malfertheiner, P. (2001) A meta-analysis comparing eradication, healing and relapse rates in patients with Helicobacter pylori-associated gastric or duodenal ulcer. Alimentary Pharmacology \& Therapeutics, 15, 1949-1958. http://dx.doi.org/10.1046/j.1365-2036.2001.01109.x

[43] Huang, J.Q., Sridhar, S. and Hunt, R.H. (2002) Role of Helicobacter pylori infection and non-steroidal anti-inflammatory drugs in peptic-ulcer disease: A meta-analysis. Lancet, 359, 14-22. http://dx.doi.org/10.1016/S0140-6736(02)07273-2

[44] Malfertheiner, P., Megraud, F., O’Morain, C.A., Atherton, J., Axon, A.T., Bazzoli, F., Gensini, G.F., Gisbert, J.P., Graham, D.Y., Rokkas, T., El-Omar, E.M., Kuipers, E.J. and European Helicobacter Study Group. (2012) Management of Helicobacter pylori infection-The Maastricht IV/ Florence Consensus Report. Gut, 61, 646-664. http://dx.doi.org/10.1136/gutjnl-2012-302084

[45] Hawkey, C.J. (1999) Personal review: Helicobacter pylori, NSAIDs and cognitive dissonance. Alimentary Pharmacology \& Therapeutics, 13, 695-702. http://dx.doi.org/10.1046/j.1365-2036.1999.00550.x

[46] Dell Valle, J., Chey, W. and Scheimann, J. (2003) Acid peptic disorders. Lippincott Williams \& Wilkins, Philadelphia.

[47] Sonnenberg, A. (1997) Peptic ulcer. In: Johanson, J.A., Ed., Gastrointestinal Diseases: Risks Factors and Prevention. Lippincott-Raven, New York, 45-65.

[48] Misciagna, G., Cisternino, A.M. and Freudenheim, J. (2000) Diet and duodenal ulcer. Digestive and Liver Diseases, 32, 468-472. http://dx.doi.org/10.1016/S1590-8658(00)80002-X

[49] Matos, J.I., de Sousa, H.A., Marcos-Pinto, R. and DinisRibeiro, M. (2013) Helicobacter pylori CagA and VacA genotypes and gastric phenotype: A meta-analysis. European Journal of Gastroenterology and Hepatology, 25, 1431-1441. http://dx.doi.org/10.1097/MEG.0b013e328364b53e

[50] Hussein, N.R. (2010) The association of dupA and Helicobacter pylori-related gastroduodenal diseases. European Journal of Clinical Microbiological and Infectious Diseases, 29, 817-821. http://dx.doi.org/10.1007/s10096-010-0933-z

[51] Roesler, B.M., Oliveira, T.B., Costa, S.C.B. and Zeitune, J.M.R. (2012) Is there any relationship between Helicobacter pylori dupA gene and the development of early and advanced gastric cancer in Brazilian patients? Journal of Medical Research and Science, 2, 15-24.

[52] Gisbert, J.P. and Calvet, X. (2011) Review article: Common misconceptions in the management of Helicobacter pylori-associated gastric MALT-lymphoma. Alimentary Pharmacology \& Therapeutics, 34, 1047-1062.

http://dx.doi.org/10.1111/j.1365-2036.2011.04839.x

[53] Jonkers, D., Gisbertz, I., Bruine, A., Bot, F., Arends, J.W., Stobberingh, E., Schouten, H. and Stockbrügger, R. (1997) Helicobacter pylori and non-Helicobacter pylori bacterial flora in gastric mucosal and tumour specimens of patients with primary gastric lymphoma. European Journal of Clinical Investigation, 27, 885-892.

http://dx.doi.org/10.1046/j.1365-2362.1997.1940756.x

[54] Gisbert, J.P. (1998) Is gastric lymphoma an infectious disease? Medicina Clinica, 110, 56-61.

[55] Dogusoy, G., Karayel, F.A., Göcener, S. and Göksel, S. (1999) Histopathologic features and expression of Bcl-2 and p53 proteins in primary gastric lymphomas. Pathology and Oncology Research, 5, 36-40. http://dx.doi.org/10.1053/paor.1999.0036

[56] Isaacson, P. and Wright, D.H. (1983) Malignant lymphoma of mucosa-associated lymphoid tissue. A distinctive type of B-cell lymphoma. Cancer, 52, 1410-1416. http://dx.doi.org/10.1002/1097-0142(19831015)52:8<141 0::AID-CNCR2820520813>3.0.CO;2-3

[57] Wang, F., Meng, W., Wang, B. and Qiao, L. (2013) Helicobacter pylori-induced gastric inflammation and gastric cancer. Cancer Letters. http://dx.doi.org/10.1016/j.canlet.2013.08.016

[58] Asenjo, L.M. and Gisbert, J.P. (2007) Prevalence of Helicobacter pylori infection in gastric MALT lymphoma: A systematic review. Revista Española de Enfermedades Digestivas, 99, 398-404.

[59] Genta, R.M., Hamner, H.W. and Graham, D.Y. (1993) Gastric lymphoid follicles in Helicobacter pylori infection: Frequency, distribution, and response to triple therapy. Human Pathology, 24, 577-583. http://dx.doi.org/10.1016/0046-8177(93)90235-9

[60] Isaacson, P.G. (1994) Gastrointestinal lymphoma. Human Pathology, 25, 1020-1029. http://dx.doi.org/10.1016/0046-8177(94)90060-4

[61] Wotherspoon, A.C., Ortiz-Hidalgo, C., Falzon, M.R. and Isaacson, P.G. (1991) Helicobacter pylori-associated gastritis and primary B-cell gastric lymphoma. Lancet, 338, 1175-1176. http://dx.doi.org/10.1016/0140-6736(91)92035-Z

[62] Eidt, S., Stolte, M. and Fischer, R. (1994) Helicobacter pylori gastritis and primary gastric non-Hodgkin's lymphomas. Journal of Clinical Pathology, 47, 436-439. http://dx.doi.org/10.1136/jcp.47.5.436

[63] Nakamura, S., Yao, T., Aoyagi, K., Iida, M., Fujishima, M. and Tsuneyoshi, M. (1997) Helicobacter pylori and primary gastric lymphoma. A histopathologic and immunohistochemical analysis of 237 patients. Cancer, 79, 3-11. http://dx.doi.org/10.1002/(SICI)1097-0142(19970101)79: $1<3::$ AID-CNCR2>3.0.CO;2-P

[64] Nakamura, S., Aoyagi, K., Furuse, M., Suekane, H., Matsumoto, T., Yao, T., Sakai, Y., Fuchigami, T., Yamamoto, I., Tsuneyoshi, M. and Fujishima, M. (1998) B-cell monoclonality precedes the development of gastric MALT lymphoma in Helicobacter pylori-associated chronic ga- 
stritis. American Journal of Pathology, 152, 1271-1279.

[65] Enno, A., O’Rourke, J.L., Howlett, C.R., Jack, A., Dixon, M.F. and Lee, A. (1995) MAL Toma-like lesions in the murine gastric mucosa after long-term infection with $\mathrm{He}$ licobacter felis. A mouse model of Helicobacter pyloriinduced gastric lymphoma. American Journal of Pathology, 147, 217-222.

[66] Ferrero, R.L., Avé, P., Radcliff, F.J., Labigne, A. and Huerre, M.R. (2000) Outbred mice with long-term Helicobacter felis infection develop both gastric lymphoid tissue and glandular hyperplastic lesions. Journal of Pathology, 191, 333-340.

http://dx.doi.org/10.1002/1096-9896(2000)9999:9999<:: AID-PATH619>3.0.CO;2-H

[67] Mueller, A., O’rourke, J., Chu, P., Chu, A., Dixon, M.F., Bouley, D.M., Lee, A. and Falkow, S. (2005) The role of antigenic drive and tumor-infiltrating accessory cells in the pathogenesis of Helicobacter-induced mucosa-associated lymphoid tissue lymphoma. American Journal of Pathology, 167, 797-812. http://dx.doi.org/10.1016/S0002-9440(10)62052-4

[68] Stolte, M., Bayerdörffer, E., Morgner, A., Alpen, B., Wündisch, T., Thiede, C. and Neubauer, A. (2002) Helicobacter and gastric MALT lymphoma. Gut, 50, III19-III24. http://dx.doi.org/10.1136/gut.50.suppl_3.iii19

[69] Zullo, A., Hassan, C., Cristofari, F., Andriani, A., Francesco, V., Ierardi, E., Tomao, S., Stolte, M., Morini, S. and Vaira, D. (2010) Effects of Helicobacter pylori eradication on early stage gastric mucosa-associated lymphoid tissue lymphoma. Clinical Gastroenterology and Hepatology, 8, 105-110. http://dx.doi.org/10.1016/j.cgh.2009.07.017

[70] Wündisch, T., Dieckhoff, P., Greene, B., Thiede, C., Wilhelm, C., Stolte, M. and Neubauer, A. (2012) Second cancers and residual disease in patients treated for gastric mucosa-associated lymphoid tissue lymphoma by Helicobacter pylori eradication and followed for 10 years. Gastroenterology, 143, 936-942. http://dx.doi.org/10.1053/j.gastro.2012.06.035

[71] Ruskone-Fourmestraux, A., Fischbach, W., Aleman, B.M., Boot, H., Du, M.Q., Megraud, F., Montalban, C., Raderer, M., Savio, A. and Wotherspoon, A. (2011) EGILS consensus report. Gastric extranodal marginal zone B-cell lymphoma of MALT. Gut, 60, 747-758.

http://dx.doi.org/10.1136/gut.2010.224949

[72] Hussell, T., Isaacson, P.G., Crabtree, J.E. and Spencer, J. (1996) Helicobacter pylori-specific tumour-infiltrating T cells provide contact dependent help for the growth of malignant B cells in low-grade gastric lymphoma of mucosa-associated lymphoid tissue. Journal of Pathology, 178, 122-127. http://dx.doi.org/10.1002/(SICI)1096-9896(199602)178:2 $<122:: A I D-P A T H 486>3.0 . C O ; 2-D$

[73] Ferreri, A.J., Govi, S. and Ponzoni, M. (2013) The role of Helicobacter pylori eradication in the treatment of diffuse large B-cell and marginal zone lymphomas of the stomach. Current Opinion in Oncology, 25, 470-479. http://dx.doi.org/10.1097/01.cco.0000432523.24358.15

[74] Isaacson, P.G. and Du, M.Q. (2004) MALT lymphoma: From morphology to molecules. Nature Reviews Cancer,

\section{4, 644-653. http://dx.doi.org/10.1038/nrc1409}

[75] Rollinson, S., Levene, A.P., Mensah, F.K., Roddam, P.L., Allan, J.M., Diss, T.C., Roman, E., Jack, A., MacLennan, K., Dixon, M.F. and Morgan, G.J. (2003) Gastric marginal zone lymphoma is associated with polymorphisms in genes involved in inflammatory response and antioxidative capacity. Blood, 102, 1007-1011. http://dx.doi.org/10.1182/blood-2002-12-3803

[76] Liu, H., Ye, H., Ruskone-Fourmestraux, A., Jong, D., Pileri, S., Thiede, C., Lavergne, A., Boot, H., Caletti, G., Wündisch, T., Molina, T., Tall, B.G., Elena, S., Thomas, T., Zinzani, P.L., Neubauer, A., Stoltle, M., Hamoudi, R.A., Dogan, A., Isaacson, P.G. and Du, M.Q. (2002) $\mathrm{T}(11 ; 18)$ is a marker for all stage gastric MALT lymphomas that will not respond to $H$. pylori eradication. Gastroenterology, 122, 1286-1294.

http://dx.doi.org/10.1053/gast.2002.33047

[77] Du, M.Q. (2007) MALT lymphoma: Recent advances in aetiology and molecular genetics. Journal of Clinical and Experimental Hematopathology, 47, 31-42. http://dx.doi.org/10.3960/jslrt.47.31

[78] Auer, I.A., Gascoyne, R.D., Connors, J.M., Cotter, F.E., Greiner, T.C., Sanger, W.G. and Horsman, D.E. (1997) $\mathrm{t}(11 ; 18)(\mathrm{q} 21 ; \mathrm{q} 21)$ is the most common translocation in MALT lymphomas. Annals of Oncology, 8, 979-985. http://dx.doi.org/10.1023/A:1008202303666

[79] Ott, G., Katzenberger, T., Greiner, A., Kalla, J., Rosenwald, A., Heinrich, U., Ott, M.M. and Müller-Hermelink, H.K. (1997) The $t(11 ; 18)(q 21 ; q 21)$ chromosome translocation is a frequent and specific aberration in low-grade but not high-grade malignant non-Hodgkin's lymphomas of the mucosa-associated lymphoid tissue (MALT-) type. Cancer Research, 57, 3944-3948.

[80] Du, M.Q., Peng, H., Liu, H., Hamoudi, R.A., Diss, T.C., Willis, T.G., Ye, H., Dogan, A., Wotherspoon, A.C., Dyer, M.J. and Isaacson, P.G. (2000) BCL10 gene mutation in lymphoma. Blood, 95, 3885-3890.

[81] Koehler, C.I., Mues, M.B., Dienes, H.P., Kriegsmann, J., Schirmacher, P. and Odenthal, M. (2003) Helicobacter pylori genotyping in gastric adenocarcinoma and MALT lymphoma by multiplex PCR analyses of paraffin wax embedded tissues. Molecular Pathology, 56, 36-42. http://dx.doi.org/10.1136/mp.56.1.36

[82] Ferreira-Chagas, B., Lasne, G., Dupouy, S., Gallois, A., Morgner, A., Ménard, A., Mégraud, F. and Lehours, P. (2007) In vitro proinflammatory properties of Helicobacter pylori strains causing low-grade gastric MALT lymphoma. Helicobacter, 2, 616-617.

http://dx.doi.org/10.1111/j.1523-5378.2007.00546.x

[83] Lehours, P., Ménard, A., Dupouy, S., Bergey, B., Richy, F., Zerbib, F., Ruskoné-Fourmestraux, A., Delchier, J.C. and Mégraud, F. (2004) Evaluation of the association of nine Helicobacter pylori virulence factors with strains involved in low-grade gastric mucosa-associated lymphoid tissue lymphoma. Infection and Immunity, 72, 880-888. http://dx.doi.org/10.1128/IAI.72.2.880-888.2004

[84] Malfertheiner, P., Bornschein, J. and Selgrad, M. (2010) Role of Helicobacter pylori infection in gastric cancer pathogenesis: A chance for prevention. Journal of Digestive Diseases, 11, 2-11. 
http://dx.doi.org/10.1111/j.1751-2980.2009.00408.x

[85] Nardone, G., Rocco, A. and Malfertheiner, P. (2004) Review article: Helicobacter pylori and molecular events in precancerous gastric lesions. Alimentary Pharmacology \& Therapeutics, 20, 261-270. http://dx.doi.org/10.1111/j.1365-2036.2004.02075.x

[86] Hohenberger, P. and Gretschel, S. (2003) Gastric cancer. Lancet, 362, 305-315. http://dx.doi.org/10.1016/S0140-6736(03)13975-X

[87] Bowles, M.J. and Benjamin, I.C. (2001) ABC of the upper gastrointestinal tract. Cancer of the stomach and pancreas. British Medical Journal, 323, 1413-1416. http://dx.doi.org/10.1136/bmj.323.7326.1413

[88] Lauren, P. (1975) The two histological main types of gastric carcinoma: Diffuse and so called intestinal type carcinoma. Acta Pathologica et Microbiologica Scandinavica, 64, 31-49.

[89] Sugiyama, T. and Asaka, M. (2004) Helicobacter pylori infection and gastric cancer. Medical Eletron Microscopy, 37, 149-157. http://dx.doi.org/10.1007/s00795-004-0250-7

[90] Correa, P., Haenszel, W., Cuello, C., Tannenbaum, S. and Archer, M. (1975) A model for gastric cancer epidemiology. Lancet, 306, 58-60. http://dx.doi.org/10.1016/S0140-6736(75)90498-5

[91] Correa, P. (1988) A human model of gastric carcinogenesis. Cancer Research, 48, 3554-3560.

[92] Correa, P. (1992) Human gastric carcinogenesis: A multisptep and multifactorial process-First American Cancer Society Award lecture on cancer epidemiology and prevention. Cancer Research, 52, 6735-6740.

[93] Correa, P. and Piazuelo, M.B. (2012) The gastric precancerous cascade. Journal of Digestive Diseases, 13, 2-9. http://dx.doi.org/10.1111/j.1751-2980.2011.00550.x

[94] Everett, S.M. and Axon, A.T.R. (1998) Early gastric cancer: Disease or pseudo-disease? Lancet, 351, 1350-1352. http://dx.doi.org/10.1016/S0140-6736(98)04365-7

[95] Censini, S., Lange, C. and Xiang, Z. (1996) cag, a pathogenicity island of Helicobacter pylori, encodes type I-specific and disease-associated virulence factors. Proceedings of the National Academy of Sciences of the United States of America, 93, 14648-14651. http://dx.doi.org/10.1073/pnas.93.25.14648

[96] Franco, A.T., Johnson, E., Krishna, U., Yamaoka, Y., Israel, D.A., Nagy, T.A., Wroblewski, L.E., Piazuelo, M.B., Correa, P. and Peek Jr., R.M. (2008) Regulation of gastric carcinogenesis by Helicobacter pylori virulence factors. Cancer Research, 68, 379-387. http://dx.doi.org/10.1158/0008-5472.CAN-07-0824

[97] Parsonnet, J., Friedman, G.D., Orentreich, N. and Vogelman, H. (1997) Risk for gastric cancer in people with CagA positive or CagA negative Helicobacter pylori infection. Gut, 40, 297-301.

[98] Kuipers, E.J., Perez-Perez, G.I., Meuwissen, S.G.M. and Blaser, M.J. (1995) Helicobacter pylori and atrophic gastritis: Importance of the cagA status. Journal of the National Cancer Institute, 87, 1777-1780.

http://dx.doi.org/10.1093/jnci/87.23.1777
[99] Blaser, M.J., Perez-Perez, G.I., Kleanthous, H., Cover, T.L., Peek, R.M., Chyou, P.H., Stemmermann, G.N. and Nomura, A. (1995) Infection with Helicobacter pylori strains possessing cagA is associated with an increased risk of developing adenocarcinoma of the stomach. Cancer Research, 55, 2111-2115.

[100] Wang, S.H., Zhu, H.F., He, B.S., Zhang, Z.Y., Chen, Z.T., Wang, Z.Z. and Wu, G.L. (2007) cagA + H. pylori infection is associated with polarization of $\mathrm{T}$ helper cell immune responses in gastric carcinogenesis. World Journal of Gastroenterology, 13, 2923-2931.

[101] Roesler, B.M., Costa, S.C.B. and Zeitune, J.M.R. (2011) Virulence factors of Helicobacter pylori and their relationship with the development of early and advanced distal intestinal type gastric adenocarcinoma. In: Gastritis and Gastric Cancer. New Insights in Gastroprotection, Diagnosis and Treatments. Paola Tonino, Rijeka, 1, 259280.

[102] Odenbreit, S., Puls, J., Sedlmaier, B., Gerland, E., Fischer, W. and Haas, R. (2000) Translocation of Helicobacter pylori CagA into gastric epithelial cells by type IV secretion. Science, 287, 1497-1500. http://dx.doi.org/10.1126/science.287.5457.1497

[103] Higashi, H., Tsutsumi, R., Muto, S., Sugiyama, T., Azuma, T., Asaka, M. and Hatakeyama, M. (2002) SHP-2 tyrosine phosphatase as an intracellular target of Helicobacter pylori CagA protein. Science, 295, 683-686.

[104] Franco, A.T., Israel, D.A., Washington, M.K., et al. (2005) Activation of $\beta$-catenin by carcinogenic Helicobacter pylori. Proceedings of the National Academy of Sciences of the United States of America, 102, 10646-10651. http://dx.doi.org/10.1073/pnas.0504927102

[105] Murata-Kamiya, N., Kurashima, Y., Teishikata, Y., Yamahashi, Y., Saito, Y., Higashi, H., Aburatani, H., Akiyama, T., Peek Jr., R.M., Azuma, T. and Hatakeyama, M. (2007) Helicobacter pylori CagA interacts with E-cad- herin and deregulates the $\beta$-catenin signal that promotes intestinal transdifferentiation in gastric ephitelial cells. Oncogene, 26, 4617-4626. http://dx.doi.org/10.1038/sj.onc.1210251

[106] Amieva, M.R., Vogelmman, R., Covacci, A., Tompkins, L.S., Nelson, W.J. and Falkow, S. (2003) Disruption of the epithelial apical-junctional complex by Helicobacter pylori CagA. Science, 300, 1430-1434. http://dx.doi.org/10.1126/science.1081919

[107] Suzuki, M., Mimuro, H., Suzuki, T., Park, M., Yamamoto, T. and Sasakawa, C. (2005) Interaction of CagA with Crk plays an important role in Helicobacter pylori-induced loss of gastric epithelial cell adhesion. The Journal of Experimental Medicine, 202, 1235-1247. http://dx.doi.org/10.1084/jem.20051027

[108] Bagnoli, F., Buti, L., Tompkins, L., Covacci, A. and Amieva, M.R. (2005) Helicobacter pylori CagA induces a transition from polarized to invasive phenotypes in MDCK cells. Proceedings of the National Academy of Sciences of the United States of America, 102, 16339-16344. http://dx.doi.org/10.1073/pnas.0502598102

[109] Kabir, S. (2009) Effect of Helicobacter pylori eradication on incidence of gastric cancer in human and animal mod- 
els: Underlying biochemical and molecular events. Helicobacter, 14, 159-171.

http://dx.doi.org/10.1111/j.1523-5378.2009.00677.x

[110] Nardone, G. and Morgner, A. (2003) Helicobacter pylori and gastric malignances. Helicobacter, 8, 44-52. http://dx.doi.org/10.1046/j.1523-5378.2003.00160.x

[111] Machado, J.C., Figueiredo, C., Canedo, P., et al. (2003) A proinflammatory genetic profile increases the risk for chronic atrophic gastritis and gastric carcinoma. Gastroenterology, 125, 364-371. http://dx.doi.org/10.1016/S0016-5085(03)00899-0

[112] Hou, L., El-Omar, E.M., Chen, J., Grillo, P., Rabkin, C.S., Baccarelli, A., Yeager, M., Chanock, S.J., Zatonski, W., Sobin, L.H., Lissowska, J., Fraumeni Jr., J.F. and Chow, W.H. (2007) Polymorphisms in Th1-type cell mediated response genes and risk of gastric cancer. Carcinogenesis, 28, 118-123. http://dx.doi.org/10.1093/carcin/bgl130

[113] Wex, T., Ebert, M.P., Kropf, S., Dierkes, J., Schüttler, K., Röcken, C., Höcker, M. and Malfertheiner, P. (2008) Gene polymorphisms of the NOD-2/CARD-15 gene and the risk of gastric cancer in Germany. Anticancer Research, 28, 757-762.

[114] Santini, D., Angeletti, S., Ruzzo, A., Dicuonzo, G., Galluzzo, S., Vincenzi, B., Calvieri, A., Pizzagalli, F., Graziano, N., Ferraro, E., Lorino, G., Altomare, A., Magnani, M., Graziano, F. and Tonini, G. (2008) Toll-like receptor 4 Asp299Gly and Thr399IIe polymorphisms in gastric cancer of intestinal and diffuse histotypes. Clinical and Experimental Immunology, 154, 360-364. http://dx.doi.org/10.1111/j.1365-2249.2008.03776.x

[115] Pandey, R., Misra, V., Misra, S.P., et al. (2010) Helicobacter pylori and gastric cancer. Asian Pacific Journal of
Cancer Prevention, 11, 583-588.

[116] Ngoan, L.T., Mizoue, T., Fujino, Y., Tokui, N. and Yoshimura, T. (2002) Dietary factors and stomach cancer mortality. British Journal of Cancer, 87, 37-42.

http://dx.doi.org/10.1038/sj.bjc.6600415

[117] Chao, A., Thun, M.J., Henley, S.J., Jacobs, E.J., McCullough, M.L. and Calle, E.E. (2002) Cigarette smoking, use of other tobacco products and stomach cancer mortality in US adults: The cancer prevention study II. International Journal of Cancer, 101, 380-389.

http://dx.doi.org/10.1002/ijc.10614

[118] Nishino, Y., Inoue, M., Tsuji, I., Wakai, K., Nagata, C., Mizoue, T., Tanaka, K. and Tsugane, S. (2006) Tobacco smoking and gastric cancer risk: An evaluation based on a systematic review of epidemiologic evidence among the Japanese population. Japanese Journal of Clinical Oncology, 36, 800-807. http://dx.doi.org/10.1093/jjco/hyl112

[119] Ladeiras-Lopes, R., Pereira, A.K., Nogueira, A., PinheiroTorres, T., Pinto, I., Santos-Pereira, R. and Lunet, N. (2008) Smoking and gastric cancer: Systematic review and metaanalysis of cohort studies. Causes Cancer \& Control, 19, 689-701. http://dx.doi.org/10.1007/s10552-008-9132-y

[120] Steevens, J., Schouten, L.J., Goldbohm, R.A. and van den Brandt, P.A. (2010) Alcohol consumption, cigarette smoking and risk of subtypes of oesophageal and gastric cancer: A prospective cohort study. Gut, 59, 39-48. http://dx.doi.org/10.1136/gut.2009.191080

[121] Gerhard, M., Rad, R., Prinz, C. and Naumann, M. (2002) Pathogenesis of Helicobacter pylori infection. Helicobacter, 7, 17-23.

http://dx.doi.org/10.1046/j.1523-5378.7.s1.3.x 